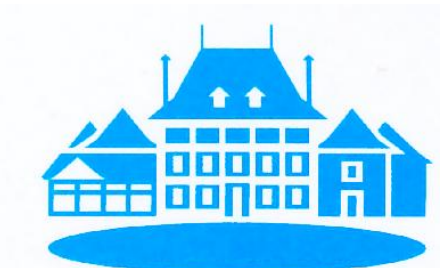

STUDY CENTER

GERZENSEE

\title{
Deciding to Peg the Exchange Rate in Developing Countries: The Role of Private-Sector Debt
}

\author{
Philipp Harms and Mathias Hoffmann
}

Working Paper 09.06

This discussion paper series represents research work-in-progress and is distributed with the intention to foster discussion. The views herein solely represent those of the authors. No research paper in this series implies agreement by the Study Center Gerzensee and the Swiss National Bank, nor does it imply the policy views, nor potential policy of those institutions. 


\title{
Deciding to Peg the Exchange Rate in Developing Countries: The Role of Private-Sector Debt
}

\author{
by \\ Philipp Harms (RWTH Aachen University and Study Center Gerzensee) \\ and \\ Mathias Hoffmann (Deutsche Bundesbank) ${ }^{1}$
}

November 2009

\begin{abstract}
$\underline{\text { Abstract: }}$
We argue that a higher share of the private sector in a country's external debt raises the incentive to stabilize the exchange rate. We present a simple model in which exchange rate volatility does not affect agents' welfare if all the debt is incurred by the government. Once we introduce private banks who borrow in foreign currency and lend to domestic firms, the monetary authority has an incentive to dampen the distributional consequences of exchange rate fluctuations. Our empirical results support the hypothesis that not only the level, but also the composition of foreign debt matters for exchange-rate policy.
\end{abstract}

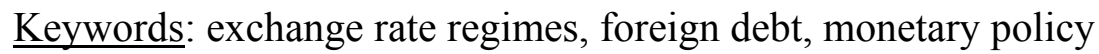

JEL classification codes: E52, F31, F41

\footnotetext{
${ }^{1}$ Philipp Harms, RWTH Aachen University, Faculty of Business and Economics, Templergraben 64/III, D52062 Aachen, Germany. Tel. +49(0)241 80-96203. Email: harms@rwth-aachen.de. Mathias Hoffmann, Economic Research, Deutsche Bundesbank, 60431 Frankfurt/Main, Germany. Tel. +49 (0)69-95666732. Email: mathias.hoffmann@bundesbank.de. The views expressed here are those of the authors and not necessarily those of the Deutsche Bundesbank.
} 


\section{Introduction}

It has long been recognized that, in many developing countries and emerging markets, a large volume of external debt denominated in foreign currency generates an incentive to stabilize the exchange rate. Hausmann et al. (2001) show that exchange-rate volatility is positively correlated to a country's ability to borrow in its own currency, and Calvo and Reinhart (2002) document that even those countries which do not announce an official peg try to avoid excessive exchange rate variations. A large number of studies has subsequently corroborated these findings by establishing a strong empirical link between countries' foreign-currencydenominated external debt and their tendency to adopt a fixed exchange rate regime.

In this paper we argue that, while the overall volume of foreign debt certainly matters for a country's exchange-rate regime choice, its composition in terms of the nature of borrowers also plays an important role. Specifically, we claim that a higher share of the private sector in a country's total external debt raises the monetary authority's propensity to adopt an explicit or implicit exchange rate target. The logic of our argument runs as follows: in the presence of nominal rigidities, any movement of the nominal exchange rate creates winners and losers. A nominal depreciation raises the effective debt burden, but also raises profits in the domestic export sector. A nominal appreciation has the opposite effect. If the government is the only debtor with respect to the rest of the world it internalizes both gains and losses: in case of a depreciation it has to raise higher taxes, but the tax burden is easier to bear for exporters who benefit from higher profits. Conversely, an appreciation reduces exporters' profits but the government faces a de-facto lower debt burden. In an extreme case, gains and losses from appreciations and depreciations exactly offset each other, and the government is indifferent towards fluctuations of the exchange rate. Once a share of foreign debt is held by private agents, the argument that aggregate losses from exchange-rate volatility are low (or completely absent) no longer holds: domestic debtors loose from a depreciation, gain from an appreciation, and unless there is a well-functioning transfer scheme, there is no way they participate in exporters' opposed economic fortunes. Hence, moving from public to private external debt drives a wedge between the winners and losers from exchange-rate fluctuations, and this generates an incentive to adopt an explicit or implicit peg.

To present this point in a transparent fashion we first develop a simple model which relates a monetary authority's decision to engage in (potentially costly) foreign-exchange intervention to the share of the private sector in total foreign debt. We then take the model's 
main hypothesis to the data and estimate how the share of private-sector debt in developing countries' total external debt affects the likelihood to adopt a fixed exchange-rate regime. It turns out that this effect is significantly positive across a wide range of specifications, samples and estimation methods, and that it is even stronger if we explicitly consider the possibility that the composition of external debt is endogenous with respect to the exchange-rate regime.

The rest of the paper is structured as follows: section 2 provides a brief survey of the relevant literature. Section 3 introduces our model. In section 4, we present the data we use, the specification of our empirical model, and the results from estimating different variations of our benchmark specification. Section 5 summarizes and concludes.

\section{Related Literature}

Given the availability of new data sets on de-jure and de-facto exchange rate regimes (Ghosh et al. 2002; Levy-Yeyati and Sturzenegger 2003; Reinhart and Rogoff 2004) several recent studies have analyzed the empirical determinants of countries' exchange-rate regimes. ${ }^{2}$ LevyYeyati et al. (2004) distinguish an "optimal-currency area view", a "political-economy view" and a "financial view" on exchange-rate regime choice and explore the importance of a wide range of potential determinants. They demonstrate that the size of a country's foreigncurrency denominated liabilities (relative to its money supply) has a strong effect on the likelihood of adopting a de-facto peg. ${ }^{3}$ Alesina and Wagner (2006) focus on the role of the institutional framework and show that while the extent of corruption, the security of property rights etc. have no impact on the likelihood of adopting a peg once they control for external liabilities, these variables are of crucial importance for the relationship between countries' announcements and their implemented policies. According to their findings, countries with bad institutions tend to allow their currencies to be more volatile than would be justified by the official exchange rate regime, while countries with good institutions exhibit a CalvoReinhart (2002) style "fear of floating." Carmignani et al. (2008) expand the set of political and institutional variables and explore how these factors affect countries' de-jure and de-facto exchange-rate regime choices. While the studies just quoted use binary dependent variables mainly dummies representing the prevalence of a de-jure or de-facto peg - von Hagen and Zhou (2007) allow for a more differentiated menu of regime choices and perform a

\footnotetext{
${ }^{2}$ Earlier empirical studies on the determinants of countries' exchange rate regimes are by Rizzo (1998), Poirson (2001), Meon and Rizzo (2002), as well as Juhn and Mauro (2002). A theoretical political-economic analysis of exchange-rate-regime choice is provided by Hefeker (1998).

${ }^{3}$ Céspedes et al. (2004) provide a theoretical justification by highlighting "balance sheet effects" as a channel through which a flexible exchange rate amplifies the consequences of economic shocks.
} 
multinomial logit analysis. They find that exchange rate regimes exhibit a high degree of persistence and that various factors affect regime choice in a non-linear fashion, making a multinomial logit preferable to an ordered logit approach.

The paper closest to our analysis is Faia et al. (2008) who describe a conflict of interest between the financial sector and exporting firms. While the latter benefit from the increase in price competitiveness resulting from a nominal depreciation, the financial sector is hurt by the increasing value of foreign-currency denominated debt. The authors focus on the political process that brings about the choice of a certain exchange-rate regime and demonstrate that a stronger influence of the respective lobbies results in greater de-facto exchange-rate stability - especially in a "bad" institutional environment that makes the government more amenable to the pressure of interest groups. While the central argument of our paper is also based on the distributional effects of exchange rate fluctuations, our analysis substantially differs from Faia et al. (2008) by concentrating on the composition of external debt and by emphasizing the distinct roles of private and public liabilities. This difference is also at the heart of our empirical analysis, and the share of the private sector in a country's total external debt is the key regressor in our investigation. ${ }^{4}$

\section{A Simple Model of Private Foreign Debt and Exchange Rate Stabilization}

\subsection{Basic Structure and Assumptions}

We consider a small open economy that consists of a monetary authority and a population whose total mass is normalized to one. Agents live for one period, receive an exogenous nonmarket income $X$ and a market income $Y$, which can either be derived from entrepreneurial activity or from financial intermediation. ${ }^{5}$ There are $n$ financial intermediaries ("banks") who borrow abroad and lend to domestic entrepreneurs, and (1- $n)$ "entrepreneurs" who use the borrowed resources to produce a homogenous good whose price is normalized to one. In what follows, we assume that $0 \leq n<1$ and we denote a bank's (entrepreneur's) market income by $Y^{B}\left(Y^{E}\right)$. At the end of their lives, agents consume their entire income, which yields utility $U=\ln \left(X+Y^{k}\right)$, with $k \in\{B, E\}$.

\footnotetext{
${ }^{4}$ By contrast, Faia et al. (2008) multiply the size of the financial sector (relative to GDP) with a country's foreign-currency-denominated liabilities.

5 Given that agents' market income is subject to fluctuations, their non-market income prevents consumption from turning negative.
} 
The country's total external borrowing at the beginning of the period $(D)$ is measured in foreign currency units and normalized to one. By assumption, each bank borrows one unit, hence total private external debt equals $D^{P}=n$ and total public external debt is given by $D^{G}=1-n$. Both banks and the government borrow at a gross foreign interest rate $R^{*}$ which is normalized to one for simplicity. While banks lend the borrowed funds to entrepreneurs at a gross interest rate $R$ (repayable in domestic currency units), the government uses these funds to finance a public infrastructure. At the end of the period, banks and government have to repay their foreign liabilities whose value in domestic currency units is then determined by the nominal exchange rate $S$ (in price notation). The government meets its repayment obligations by raising taxes $T$ from entrepreneurs, while banks use the principal and interest received from domestic entrepreneurs. Note that a nominal depreciation increases the end-ofperiod debt burden for both banks and government, and that $T=S \cdot D^{G}$. Hence, the tax paid by entrepreneur $i$ is $T_{i}=S \cdot D^{G} /(1-n)$.

Banks' total foreign borrowing $\left(D^{P}\right)$ is allocated uniformly among domestic entrepreneurs, hence an individual entrepreneur borrows the amount $D^{P} /(1-n)$. The income of entrepreneur i before taxes and before debt repayment increases in the amount borrowed from banks, in the size of the public infrastructure, and in the nominal exchange rate. More specifically, we assume that

$$
Y_{i}^{E}=S\left(\frac{D^{P}+D^{G}}{1-n}\right)-R \frac{D^{P}}{1-n}
$$

Private debt $\left(D^{P}\right)$ has a positive influence on $Y_{i}^{E}$ since entrepreneurs use the borrowed funds to finance investment. The positive effect of $D^{G}$ on $Y_{i}^{E}$ can be rationalized by the assumption that a publicly financed infrastructure raises firms' productivity. Linearity is assumed for simplicity. Finally, the fact that a nominal depreciation raises $Y_{i}^{E}$ while a nominal appreciation reduces $Y_{i}^{E}$ follows from exporters' "pricing to market" behavior: if firms fix their prices in foreign-currency terms before the nominal exchange rate is realized and if their costs are not affected by exchange rate fluctuations, a depreciation increases profits in domestic currency units.

The market income of bank $j$ is given by the difference between (domestic currency) receipts on loans to entrepreneurs and repayment obligations in foreign currency, i.e. 


$$
Y_{j}^{B}=R-S
$$

As we will see below, none of our results depends on the value of the domestic interest rate $R$. While we could easily endogenize this variable by assuming a particular market structure in the financial sector and by computing the equilibrium price of domestic loans, this would add no important insights. For the sake of simplicity we therefore treat $R$ like an exogenous variable.

At the end of the period, there is an exogenous shock $\widetilde{S}$ to the nominal exchange rate, which the monetary authority may fight by intervening in foreign-exchange markets. Intervention comes at a cost $\kappa$ which depends on the difference between the shock and the exchange rate the monetary authority implements. More specifically, $\kappa=\frac{\gamma}{2}(S-\tilde{S})^{2}$ with $\gamma \geq$ 0 . Once $\widetilde{S}$ is realized, the monetary authority chooses $S$ to maximize the following objective function:

$$
V^{G}=n \ln \left(X+Y_{j}^{B}\right)+(1-n) \ln \left(X+Y_{i}^{E}-T_{i}\right)-\frac{\gamma}{2}(S-\widetilde{S})^{2}
$$

\subsection{Private Foreign Debt and Exchange-Rate Volatility}

Using (1) and the fact that $T_{i}=S \cdot D^{G} /(1-n)$ it is easy to show that citizens' end-of-period consumption is unaffected by exchange rate fluctuations if $n=0$, i.e. if all foreign borrowing is done by the government. This is due to the fact that both their gross income and their tax burden increases in $S \cdot D^{G}$. Hence, while a nominal depreciation benefits entrepreneurs by generating higher incomes before taxes, it hurts them by raising the taxes they have to pay. A nominal appreciation produces the opposite effect. This result is clearly owed to the simple structure of our model, but it conveys a more general message: the government's higher debt burden resulting from a depreciation is passed on to citizens in the form of higher taxes. If the same citizens benefit from a depreciation due to higher gross incomes, the impact of exchange-rate fluctuations on welfare is dampened. In the extreme case of our model, gains and losses cancel out, and the government has no incentive to intervene in foreign-exchange markets. 
If $n>0$, i.e. if there are both bankers and entrepreneurs, average end-of-period consumption $\bar{C}$ is still unaffected by the exchange rate, i.e.

$$
\bar{C}=n\left(X+Y_{j}^{B}\right)+(1-n)\left(X+Y_{i}^{E}-T_{i}\right)=X
$$

Hence, in our model exchange rate fluctuations are purely redistributive: while a nominal depreciation increases entrepreneurs' income (before and after taxes), it reduces the income of banks, with both changes exactly offsetting each other.

To analyze how the monetary authority's optimal choice of the exchange rate $\left(S^{*}\right)$ for a given shock $\widetilde{S}$ is affected by the presence of private foreign borrowing, we substitute (1) and (2) into (3), bearing in mind that $T_{i}=S \cdot D^{G} /(1-n)$, and set the derivative with respect to $S$ equal to zero. This yields the following expression:

$$
\begin{aligned}
& S^{*}-R=\omega(n)(\widetilde{S}-R), \\
& \text { with } \quad \omega(n)=\frac{\gamma \Omega}{\gamma \Omega+\frac{n}{1-n}} \\
& \text { and } \quad \Omega=\left(X+Y_{j}^{B}\right)\left(X+Y_{i}^{E}-T_{i}\right)>0 .
\end{aligned}
$$

Assuming that bankers' and entrepreneurs' consumption never turns negative, i.e. $\Omega>0$ in all states of nature, we have $0 \leq \omega(n) \leq 1$ for all $n \in[0,1)$. Let's start by considering three special cases: if $\gamma=0$, i.e. if foreign exchange market intervention is costless, the monetary authority chooses to perfectly stabilize the exchange rate, and $S^{*}=R$. Conversely, if these costs are close to infinity, the monetary authority allows the exchange rate to be determined by the exogenous shock, i.e. $S^{*}=\widetilde{S}$. Finally, if $\gamma$ is strictly positive and finite, but $n=0$ then $S^{*}=\widetilde{S}$ as well. This is just the result outlined at the start of this subsection: agents' consumption is unaffected by exchange rate fluctuations in this case, and the monetary authority has no incentive to influence the exchange rate.

If, however, the costs of stabilization are strictly positive and $n>0$, the monetary authority chooses to stabilize the exchange rate to some extent: since $0<\omega(n)<1$, deviations of $S^{*}$ from $R$ are smaller than deviations of $\widetilde{S}$ from $R$. In fact, using (1) and (2) it can be 
shown that $\omega^{\prime}(n)<0$ : an increasing number of banks - i.e. an increasing share of the private sector in total external debt - raises the government's incentive to stabilize the exchange rate. The logic behind this result is straightforward: while average consumption is unaffected by the public vs. private decomposition of foreign debt, a strictly positive number of banks reflects the existence of a group of agents who definitely lose from a depreciation. Conversely, entrepreneurs unambiguously gain from the domestic currency's loss in value, and the opposite holds for an appreciation. Since the government maximizes the sum of all agents' utilities and since utility functions are concave it decides to completely stabilize the exchange rate if this is costless. If the costs of foreign exchange intervention are strictly positive the government faces a tradeoff, but unless $\gamma$ is infinite it avoids excessive fluctuations of the exchange rate.

\section{Private Sector Debt and the Choice of an Exchange Rate Regime: An Empirical Exploration}

\subsection{Model Specification}

The simple model of the preceding section suggests that an increasing share of the private sector in total external debt ceteris paribus raises the likelihood that a country stabilizes its nominal exchange rate. To test this hypothesis we estimate variants of the following equation:

$$
\operatorname{Peg}_{i t}=\beta_{0}+\beta_{1} \text { PRIVSHARE } E_{i t-1}+\sum_{k=1}^{K} \delta_{k} x_{k, i t}+\xi_{t}+\varepsilon_{i t}
$$

In equation (6), $P e g_{i t}$ is a dummy variable which is one if country $i$ adopted a peg in period $t$, and zero otherwise. PRIVSHARE $E_{i t-1}$ is the share of the private sector in country i's total longterm external debt at the end of period $t-1$. According to our model, the coefficient $\beta_{1}$ should be strictly positive. By using the lagged value of PRIVSHARE we are trying to mitigate the problem that private-sector debt in period $t$ might be affected by the exchange rate regime. We will later account for the possible endogeneity of our key regressor by using instrumental variable estimation.

The variables $x_{k, i t}$ are control variables, some of which are lagged by one period, $\xi_{t}$ is a time-dummy, and $\varepsilon_{i t}$ the error term. It is quite likely that the variance of $\varepsilon_{i t}$ differs 
systematically across countries and that the error term exhibits a high degree of persistence. We therefore put as little restrictions as possible on the joint distribution of $\varepsilon_{i t}$, and all standard errors are based on a robust covariance matrix which allows for heteroscedasticity and arbitrary serial correlation within clusters. ${ }^{6}$

We will first estimate equation (6) by OLS. While this "linear probability model" has the unattractive property that the fitted values of the dependent variable - interpreted as the probability that a country chooses a peg - do not necessarily fall into the interval between zero and one, it offers the advantage of not depending on a particular assumption about the distribution of the error term. As an alternative, we will later estimate a probit regression which is based on the latent variable model

$$
\begin{aligned}
& \operatorname{Peg}_{i t}^{*}=\beta_{0}+\beta_{1} \text { PRIVSHARE } E_{i t-1}+\sum_{k=1}^{K} \delta_{k} x_{k, i t}+\xi_{t}+\varepsilon_{i t} \\
& \operatorname{Peg}_{i t}=1\left[\operatorname{Peg}_{i t}^{*}>0\right]
\end{aligned}
$$

and the assumption that $\varepsilon_{i t}$ follows a standard normal distribution.

\subsection{Data}

\subsubsection{Regressors}

Our data set consists of annual data for developing countries and emerging markets which are covered by the World Bank's Global Development Finance. ${ }^{7}$ We are considering the time span from 1975 through 2004, and we ignore high-income countries as well as observations for countries whose population was smaller than one million in the year 2000. Our key regressor PRIVSHARE(-1) is computed by dividing countries' long-term external debt of the private sector in period $t-1$ by the sum of private and public long-term external debt. ${ }^{8}$

We are using three types of control variables: a wide array of dummy variables is meant to capture the influence of regional characteristics (Europe and Central Asia,

\footnotetext{
${ }^{6}$ Our decision to account for cluster-specific serial correlation deserves to be highlighted: if we use a mere "heteroscedasticity-robust" covariance matrix, standard errors are much lower and t-statistics much higher across the board.

${ }^{7}$ Information on the exact definition and sources of data is given in the data appendix.

${ }^{8}$ Long-term debt covers debt with a maturity of at least one year. We do not consider short-term debt since the private/public disaggregation is not available for debt with a lower maturity.
} 
Subsaharan Africa, South Asia, East Asia and Pacific, Latin America), colonial heritage (BRITISH, FRENCH) as well as the potential for and composition of foreign trade (LANDLOCK, FUELS, PRIMARY MATERIALS).

The second set of control variables captures factors which potentially vary over time, but which are unlikely to be endogenous with respect to the exchange rate regime. We therefore include them without a time lag. Specifically, we use the logarithm of countries' population size (POPULATION) and the average of the Freedom House measures of political rights and civil liberties (REPRESS). ${ }^{9}$ Our inclusion of these regressors is based on the notion that larger countries have a smaller incentive to enhance trade by pegging the exchange rate, and that more repressive regimes often control foreign exchange transactions by imposing a fixed exchange rate.

The third set of regressors consists of variables which are potentially affected by the exchange rate regime and which are therefore lagged by one period. The regressor FORLIAB(-1) represents a country's total foreign liabilities relative to its money supply in period $t-1$. This variable, which does not distinguish between private and public debt, figures prominently in many recent analyses of exchange-rate regime choice (see, e.g. Levy-Yeyati et al. 2004) and it captures the potential "balance-sheet-effects" of exchange rate fluctuations. We therefore expect it to have a positive impact on the likelihood that a country chooses a peg. ${ }^{10}$ The variable GAP_USA(-1) reflects a country's per-capita GDP relative to the USA. While we do not have a clear hypothesis on the effect of relative prosperity, this variable is possibly correlated with private-sector borrowing on international capital markets and needs to be included to avoid omitted variable bias. Similarly, a sequence of budget deficits is likely to affect both the share of the private sector in total external debt and the viability of a fixed exchange-rate regime. We therefore include the average of the central government's budget balance during the preceding three years (BUDGET_3Y(-1)) as an additional regressor. Finally, we use the measure of openness to international trade in assets (KAOPEN(-1)) developed by Chinn and Ito (2008) to capture the notion that unrestricted capital flows are incompatible with a fixed exchange rate if a country wants to preserve an autonomous monetary policy.

\footnotetext{
${ }^{9}$ Both Freedom House measures are defined on a scale between one and seven, with a value of seven indicating maximal repression.

${ }^{10}$ Surprisingly, the correlation between PRIVSHARE(-1) and FORLIAB(-1) is close to zero and statistically not significant.
} 


\subsubsection{Exchange Rate Regimes}

While earlier empirical research on the determinants and consequences of exchange rate regimes had to rely on countries' official announcements, the more recent contributions quoted in Section 2 use a number of "de-facto" exchange-rate regime classifications which have been developed to reflect the extent of exchange-rate stability that is actually implemented by monetary authorities. In this paper, we will use three different classifications: apart from the de-jure classification compiled by the IMF in its "Annual Report on Exchange Arrangements and Exchange Restrictions" (for a detailed description see Ghosh et al., 2002) we consider the de-facto classification developed by Levy-Yeyati and Sturzenegger (2003) as well as the "natural classification" of Reinhart and Rogoff (2004).

As described in Tavlas et al. (2008) as well as Harms and Kretschmann (2009), the three classifications have their own interpretations, merits and shortcomings: the de-facto classification of Levy-Yeyati and Sturzenegger (2003, henceforth LYS) takes into account both the volatility of the exchange rate, of exchange rate growth, and of a country's foreignexchange reserves. A peg is identified as a combination of low exchange-rate fluctuations and volatile reserves. By contrast, the "natural classification" of Reinhart and Rogoff (2004, henceforth RR) centers its attention to the observed stability of the exchange rate. However, it differs from LYS by focusing on movements of the parallel exchange rate. A peculiarity of the "natural classification" is its assignment of episodes with an inflation rate above 40 percent to a separate "freely-falling" category. As we argue in Harms and Kretschmann (2009), this approach may distort the picture if one considers the macroeconomic effects of different exchange-rate regimes. However, in the present context, it is unlikely to be important since the fraction of freely-falling episodes that would be classified as pegs is tiny. We therefore use the data from the original "natural classification" of Reinhart and Rogoff (2004). ${ }^{11}$ It is not obvious which of the three regime classifications most closely represents the forces described by the model of Section 3. It could be argued that the combination of low exchange-rate fluctuations and high reserves volatility as captured by the LYS classification reflects the active and deliberate stabilization of the exchange rate by a country's monetary authority. However, the LYS methodology's focus on the official exchange rate clearly comes as a disadvantage. Moreover, a de-facto stable rate may also be implemented through a consistent monetary policy - that is, even if the monetary authority does not intervene in

\footnotetext{
${ }^{11}$ The dataset originally compiled by Calvo and Reinhart (2004) covers the years through 2001. Following the principles of the "natural classification" Eichengreen and Razo-Garcia (2006) have recently computed de-facto exchange-rate regimes up to the year 2004. For our analysis we have merged the two datasets.
} 
foreign-exchange markets it may adjust its policy to the implicit goal of stabilizing the exchange rate. Finally, it would be wrong to dismiss a country's official regime as mere cheap talk: announcing a peg raises the costs of allowing the exchange rate to float, and we should thus interpret such an announcement as a sign that a country intends to keep the exchange rate stable. $^{12}$ Based on these arguments we will use all three classifications in the subsequent empirical analysis.

\subsubsection{Accounting for Currency Crises}

The model of section 2 is meant to describe "business as usual" in foreign exchange markets: it is not the appropriate framework to characterize behavior during a currency crisis - in particular, since exchange-rate movements during such episodes are likely to be beyond the monetary authority's control. We therefore limit our attention to periods in which no currency crisis took place. To identify currency crises we use the criteria established by Frankel and Rose (1996:352) - namely "a nominal depreciation of the currency [against the US dollar] of at least $25 \%$ that is also at least a $10 \%$ increase in the rate of depreciation." In subsequent regressions we will check whether our results are robust with respect to the inclusion of currency-crisis episodes.

\subsection{Results}

\subsubsection{OLS and Probit Estimation}

The first three columns of Table 1 present the results of estimating equation (6) by OLS. The columns refer to a de-jure peg, a peg according to LYS, and a peg according to RR, respectively. Most of the control variables have the expected sign. In particular - and in accordance with the existing literature - FORLIAB(-1) has a significantly positive influence on the likelihood of adopting a peg. Moreover, the coefficient of the budget balance is significantly positive while the negative coefficient of POPULATION indicates that, ceteris paribus, larger countries have a smaller incentive to stabilize the exchange rate. Our main variable of interest PRIVSHARE(-1) has a significantly positive coefficient: raising the share

\footnotetext{
${ }^{12}$ Note, however, that this view is not uncontested: Calvo and Reinhart (2002) and, more recently, Alesina and Wagner (2006) argue that monetary authorities in many emerging markets stabilize the exchange rate, but avoid to announce a peg to reduce the risk of speculative attacks.
} 
of the private sector in a country's external debt by one percent point increases the likelihood of a peg by approximately half a percentage point.

Columns (4) to (6) of Table 1 provide the results of estimating equation (7) using probit. For all three classifications, the main findings of the linear probability model are confirmed: PRIVSHARE(-1) has a significantly positive influence, and the marginal effects evaluated at the mean are not too different from the corresponding values of the first three columns.

\subsubsection{Instrumental Variable Estimation}

While our simple model assumed the share of the private sector in total foreign borrowing to be exogenous, we have to pay attention to the potential endogeneity of this variable when taking the model's implications to the data. It is quite plausible that private foreign borrowing is affected by the exchange rate regime: if external debt is denominated in a foreign currency, the anticipation of a stable exchange rate may lure domestic financial institutions into increasing their exposure to international capital markets. ${ }^{13}$ Using lagged regressors somewhat mitigates this problem, but our estimates may still be biased - especially since PRIVSHARE(1) represents the share of private-sector debt at the end of period $t-1$.

To account for potential endogeneity we start by estimating the linear probability model (LPM) of equation (6) using GMM. ${ }^{14}$ The instruments we use are the average quality of financial-sector regulation in the preceding three years as measured by the Fraser Institute (various issues) (CREDREG_3Y(-1)), the average inflation rate of the preceding years (INFLA_3Y(-1)) as well as the growth rate of real per-capita income in the preceding three years (GROWTH_3Y(-1)). ${ }^{15}$ We argue that a less regulated financial sector encourages private foreign borrowing while low inflation rates and high economic growth characterize a stable macroeconomic environment which is conducive to higher private foreign debt. To document that these regressors are indeed relevant, i.e. correlated with PRIVSHARE(-1), we report the p-value referring to the Kleinbergen-Paap rk-statistic for underidentification. The joint exogeneity of our instruments is checked by running Hansen's (1982) J-test. Finally, we

\footnotetext{
13 In fact, regressing PRIVSHARE(-1) on a dummy representing a fixed exchange rate regime yields a very high and statistically significant coefficient.

${ }^{14}$ In the presence of heteroscedasticity, GMM estimation is superior to standard IV estimation since it uses an endogenous weighting matrix when combining the different moment conditions. To implement this estimator we applied the ivreg2 module for Stata designed and described by Baum et al. (2007).

${ }^{15}$ To limit the influence of extremely high inflation rates without losing observations, INFLA_3Y(-1) is based on ,transformed inflation rates“ $\pi^{\text {trans }}=\pi /(1+\pi)$.
} 
compute the p-value referring to the null-hypothesis that PRIVSHARE(-1) is exogenous. We also tested the exogeneity of individual instruments by performing a series of C-("differencin-Sargan") tests. The results of these tests are available upon request. ${ }^{16}$

The first three columns of Table 2 indicate that PRIVSHARE(-1) has a positive influence on the likelihood of a peg even if we explicitly account for this regressor's potential endogeneity. Except for the LYS classification, we can reject the null-hypothesis of exogeneity at the 10-percent level, and the diagnostics of instrument relevance and exogeneity do not send clear warning signals. The coefficient of PRIVSHARE(-1) increases relative to the values displayed in Table 1: an increase of the private-sector share by one percentagepoint raises the likelihood of a peg by approximately two percent. This is surprising since we would have expected OLS to over-estimate the impact of PRIVSHARE(-1). Still, our finding is not totally implausible: if exchange rate stability has a positive and very strong impact on private foreign borrowing, this may result in a downward bias of the OLS estimator.

Columns (4) to (6) present the results of applying Newey's (1987) "minimumdistance" estimator to the probit specification of our empirical model. ${ }^{17}$ All coefficients reported are marginal effects evaluated at the mean of the regressors. Comparing these results to the first three columns, we find that the coefficient of PRIVSHARE(-1) is still positive and increases for all three exchange-rate classifications, but it is not significant for LYS. However, in this case we cannot reject the hypothesis that PRIVSHARE(-1) is exogenous. Although a test for exogeneity of the excluded instruments (Lee, 1992) does not indicate any obvious problems, the dramatic increase of the marginal effects against the linear-probability model is somewhat suspicious. This may be due to the "fairly strong assumptions" (Wooldridge 2002:472) which have to be satisfied in order to estimate a probit model with an endogenous regressor. In particular, the requirement that PRIVSHARE(-1) should have the features of a normal random variable is unlikely to be satisfied, given that this variable is never negative and equal to zero for many observations. We therefore do not take the marginal effects too seriously but take away as a result that instrumental-variable probit estimation also suggests a positive influence of private-sector debt on the likelihood of a peg.

\footnotetext{
${ }^{16}$ See Baum et al. (2007) for details.

${ }^{17}$ To implement this estimator we used the ivprobit module programmed for Stata. Overidentification restrictions were tested using the overid module programmed by Baum et al. (2006).
} 


\subsubsection{Sample Variations}

The following estimates expose our benchmark results to several variations of the sample. In doing so, we limit our attention to the linear probability model, which we estimate both by OLS and by GMM using the instrumental variables described above.

Table 3 checks whether our results are driven by the early post-Bretton-Woods phase and limits its focus to observations after 1985 - the year which Lane and Milesi-Ferretti (2007) identify as the starting point of the recent era of "financial globalization". For the dejure and the LYS classification, this considerable reduction of sample size barely affects the significance level and coefficient of PRIVSHARE(-1). For the RR classification, the coefficient drops more noticeably, and the results for the GMM-regression in column (6) indicate that it is no longer significant. Note, however, that in this case, we cannot reject the hypothesis that PRIVSHARE(-1) is exogenous. We therefore give a greater weight to the OLS results in columns (1) - (3) and conclude that the private-sector share has a positive influence on the decision to peg for all three regime classifications, even if we only consider the more recent observations.

We also explored the consequences of omitting "freely-falling" episodes - i.e. observations that were characterized by an annual inflation rate of at least 40 percent (see Reinhart and Rogoff, 2004). Table 4 indicates that this sample variation reduces the coefficient of PRIVSHARE(-1) for the de-jure classification while it barely affects it for LYS and RR. With OLS estimation, the t-statistics drop below the critical values for the tenpercent level of significance in columns (1) and (2). ${ }^{18}$ However, if we account for the potential endogeneity of private borrowing, PRIVSHARE(-1) is siginificant for all three classifications.

In Table 5, we report the results from estimating equation (6) without omitting currency-crisis episodes. This barely changes the coefficients and the associated levels of significance for the de-jure and the RR classifications. By contrast the share of the private sector in total external debt does not seem to have a significant influence on the likelihood to adopt a peg according to the LYS classification, and this holds both for OLS and for GMM estimation. To interpret the finding that PRIVSHARE(-1) is no longer a significant determinant of LYS-pegs once currency-crisis episodes are included we need to recall the essential features of the LYS classification: a peg is characterized by a combination of a stable official exchange rate and volatile foreign-exchange reserves. By definition, the exchange rate

\footnotetext{
${ }^{18}$ In both cases, the associated p-values are 11 percent.
} 
is not stable during a currency crisis. Hence, in the regressions that are based on the larger sample, the share of pegs according to the LYS classification should be smaller. ${ }^{19}$ If currency crises are more frequent with a high private-sector exposure, this may weaken the link between PRIVSHARE(-1) and the choice of LYS pegs and thus explain the results in Table 5. We conclude that our benchmark results are sensitive to the inclusion/exclusion of "non-standard" situations if a peg is defined according to the criteria of LYS. By contrast, the influence of PRIVSHARE(-1) on de-jure pegs and pegs according to the RR classification are not affected by these sample variations. In any case the positive relationship between PRIVSHARE(-1) and the likelihood to peg remains valid.

\section{Summary and Conclusions}

The key hypothesis brought forward in this paper is that not only the volume of external liabilities, but also its composition matters for a country's incentive to stabilize the exchange rate. We argue that a higher share of the private sector in total external debt drives a wedge between winners and losers from exchange-rate fluctuations. Absent another compensation mechanism, this raises the political attractiveness of adopting a peg.

Taking this hypothesis to the data we distinguish between three exchange-rate classifications: a de-jure classification which identifies pegs according to countries' announcements, the de-facto classification of Levy-Yeyati and Sturzenegger (2003) which defines a peg as a combination of stable exchange rates and volatile reserves, and the "natural classification" of Reinhart and Rogoff (2004) which focuses on the stability of the "relevant" - possibly parallel - exchange rate. Our empirical results suggest that, indeed, a higher share of the private sector in total external debt raises the likelihood of observing a peg in emerging markets and developing countries. This finding holds across a range of specifications and estimation techniques, and it comes out even stronger if we account for the potential endogeneity of private-sector debt. The result is also robust against various modifications of the sample - at least when the de-jure and the "natural" classifications are used. In case of the Levy-Yeyati and Sturzenegger classification, the low t-statistics we observe when including currency crises may be explained by referring to the principles according to which pegs are identified in this particular exchange rate classification.

We consider our results as a further step towards a better understanding of the political economy of exchange-rate regime choice. For many developing countries and emerging

\footnotetext{
${ }^{19}$ Indeed, the share of LYS-pegs in our sample decreases from 0.57 to 0.55 once we include currency crises.
} 
markets, the share of the private sector in total external borrowing has increased substantially in the recent past (Celasun and Harms, 2009). While such an increase in a given country may be explained by the monetary authority's decision to adopt an explicit or implicit peg, our results suggest that it also raises the incentive to stabilize the exchange rate. Whether such a circle of low exchange-rate volatility and large private foreign borrowing is vicious or virtuous is beyond the scope of this paper, but provides an interesting topic for future research.

\section{Data appendix}

The data consists of annual observations for 167 developing countries and emerging markets for the years 1975 to 2004 . The dependent variable is a dummy which is one if a peg is observed according to one of the following classifications:

De-jure : Dummy variable which equals one if exchange rate regime belongs to one of the following categories: dollarization, currency board, currency union, single currency peg, published basket peg, and secret basket peg. Source: Ghosh, Gulde and Wolf (2002) and IMF (various issues).

LYS: Dummy variable which equals one if exchange rate regime is a peg according to the classification of Levy-Yeyati and Sturzenegger (2005).

RR: Dummy variable which equals one if exchange rate regime is a peg according to the "natural classification" of Reinhart and Rogoff (2004). Data for the years 2002 - 2004 are taken from Eichengreen and Razo-Garcia (2006).

BUDGET_3Y(-1): Lagged three-year average of the central government's budget balance (relative to GDP). Source: International Monetary Fund (World Economic Outlook Database) CREDREG_3Y(-1): Lagged three-year average of the Fraser Institute's index of credit market regulation, ranging from 0 (minimal regulation) to 10 (maximal regulation). Source: Fraser Institute (various issues).

FORLIAB(-1): Ratio of Foreign Liabilities to Money. Source: International Monetary Fund (International Financial Statistics), line 26C/ (line $14+$ line 24).

GAP_USA(-1): Per capita GDP in constant international dollars, expressed relative to the United State (US=100) in the same year. Source: Heston et al. 2006 (Penn World Tables 6.2). GROWTH_3Y(-1): Lagged three-year average of the growth rate of real per-capita income. Source: Heston et al. 2006 (Penn World Tables 6.2). 
INFLA_3Y(-1): Lagged three-year average of the transformed growth rate of the consumer price index $\pi$. The transformation is $\pi^{\text {trans }}=\pi /(1+\pi)$. Source: World Bank (World Development Indicators).

KAOPEN(-1): Lagged value of the Chinn/Ito measure of capital-account openness. Source: Chinn and Ito (2008).

POPULATION: Natural logarithm of the population (in thousands). Source: Heston et al. 2006 (Penn World Tables 6.2).

PRIV SHARE(-1): Lagged share of private nonguaranteed long-term external debt in total long-term external debt (in percent). Source: World Bank (Global Development Finance).

REPRESS: Average of the Freedom House index of political rights and civil liberties, ranging from 1 (maximal rights) to 7 (minimal rights). Source: Freedom House (various issues).

\section{Dummy variables:}

LANDLOCK (landlocked countries), BRITISH (British legal system), FRENCH (French legal system), FUELS (Exporter of fuels), PRIMARY_MAT (Exporter of primary materials except fuels) regional dummies. Source: World Bank (World Bank GDN database ).

\section{References}

Alesina, A. and A.F. Wagner (2006): "Choosing (and Reneging on) Exchange Rate Regimes", Journal of the European Economic Association 4, 770-799.

Baum, C.F., Schaffer, M.E., Stillman, S., Wiggins, V. (2006): “overid: Stata module to calculate tests of overidentifying restrictions after ivreg, ivreg2, ivprobit, ivtobit, reg3". http://ideas.repec.org/c/boc/bocode/s396802.html

Baum, C.F., M.E. Schaffer, and S. Stillman (2007): "Enhanced routines for instrumental variables/GMM estimation and testing." Boston College Economics Working Paper No. 667.

Calvo, G. and C. Reinhart (2002): „Fear of Floating”, Quarterly Journal of Economics 107, 379-408.

Carmignani, F., F. Colombo, and P. Tirelli: "Exploring Different Views of Exchange-Rate Regime Choice", Journal of International Money and Finance 27, 1177-1197.

Celasun, Oya und Philipp Harms (2009): "Boon or Burden? The Effect of Private-Sector Debt on the Risk of Sovereign Default in Developing Countries", forthcoming in Economic Inquiry. 
Chinn, M. and H. Ito (2008): "A new measure of financial openness", Journal of Comparative Policy Analysis 10, 309-322.

Eichengreen, B. and R. Razo-Garcia (2006): "The international monetary system in the last and next 20 years", Economic Policy 21, 393-442.

Faia, E., M. Giuliodori and M. Ruta (2008): "Political pressure and exchange rate stability in emerging market economies", Journal of Applied Economics 11, 1-32.

Frankel, J. and A. Rose (1996): "Currency Crashes in Emerging Markets: An Empirical Treatment." Journal of International Economics , 351-366

Fraser Institute (various issues): Economic Freedom in the World, data available at http://www.freetheworld.com/.

Freedom House (various issues): Freedom in the World, data available at http://www.freedomhouse.org/

Ghosh, A.R., A-M. Gulde, and H.C. Wolf (2002): Exchange Rate Regimes - Choices and Consequences, Cambridge MA (MIT Press).

Hansen, L.P. (1982): "Large Sample Properties of Generalized Method of Moments Estimators." Econometrica 50, 1029-1054.

Hausmann, R., U. Panizza, and E. Stein (2001): "Why do countries float the way they float?", Journal of Development Economics 66, 387-414.

Heston, A., R. Summers and B. Aten (2006): "Penn World Table Version 6.2", Center for International Comparisons of Production, Income and Prices at the University of Pennsylvania.

International Monetary Fund (various issues): Annual report on exchange arrangements and exchange restrictions.

Juhn, G. and P. Mauro (2002): "Long-Run Determinants of Exchange Rate Regimes: A Simple Sensitivity Analysis”, IMF Working Paper 02/104.

Lane, P. and G.M. Milesi-Ferretti (2007): “The External Wealth of Nations Mark II: Revised and Extended Estimates of Foreign Assets and Liabilities, 1970-2004", Journal of International Economics, 223-250.

Lee, L. (1992): “Amemiya's Generalized Least Squares and Tests of Overidenfication in Simultaneous Equation Models with Qualitative or Limited Dependent Variables". Econometric Reviews 11, 319-328.

Levy-Yeyati, E. and F. Sturzenegger (2003): „To Float or to Fix: Evidence on the Impact of Exchange Rate Regimes on Growth", American Economic Review 93, 1173-1193.

Levy-Yeyati, E. and F. Sturzenegger (2005): „Classifying Exchange Rate Regimes: Deeds vs. Words", European Economic Review 49, 1603-1635. 
Levy-Yeyati, E., F. Sturzenegger, and I. Reggio (2004): „On the Endogeneity of Exchange Rate Regimes", Revised version of Universidad Torcuato di Tella Business School Working Paper 11/2002.

Meon, P.-G. and J.-M. Rizzo (2002): "The viability of fixed exchange rate commitments: Does politics matter? A theoretical and empirical investigation" Open Economies Review 13, 111-132.

Newey, W.K. (1987): "Efficient Estimation of Limited Dependent Variable Models with Endogeneous Explanatory Variables". Journal of Econometrics 36, 231-250.

Poirson, H. (2001): "How Do Countries Choose Their Exchange Rate Regime?", IMF Working Paper 01/46.

Reinhart, C. and K. Rogoff (2004): „The Modern History of Exchange Rate Arrangements: A Reinterpretation“, Quarterly Journal of Economics 119, 1-48.

Rizzo, J.-M. (1998): "The Economic Determinants of the Choice of an Exchange Rate Regime: A Probit Analysis", Economics Letters 59, 283-287.

Tavlas, G., H. Dellas, and A. Stockman (2008): "The classification and performance of alternative exchange-rate regimes", European Economic Review 52, 941-963.

Von Hagen, J. and J. Zhou (2007): „The Choice of Exchange Rate Regimes in Developing Countries: A Multinomial Panel Analysis“,Journal of International Money and Finance 26, 1071-1094.

Wooldridge, J. A. (2002): "Econometric Analysis of Cross-Section and Panel Data", MIT Press. 


\section{Tables}

Table 1: Benchmark Specification - OLS and Probit Estimation

\begin{tabular}{|c|c|c|c|c|c|c|}
\hline & $\begin{array}{c}(1) \\
\text { Peg (De-jure) } \\
\text { OLS }\end{array}$ & $\begin{array}{c}(2) \\
\text { Peg (LYS) } \\
\text { OLS }\end{array}$ & $\begin{array}{c}\text { (3) } \\
\text { Peg (RR) } \\
\text { OLS }\end{array}$ & $\begin{array}{c}(4) \\
\text { Peg (De-jure) } \\
\text { Probit }\end{array}$ & $\begin{array}{c}\text { (5) } \\
\text { Peg (LYS) } \\
\text { Probit }\end{array}$ & $\begin{array}{c}\text { (6) } \\
\text { Peg (RR) } \\
\text { Probit }\end{array}$ \\
\hline PRIVSHARE(-1) & $\begin{array}{c}0.416^{* *} \\
{[0.197]}\end{array}$ & $\begin{array}{c}0.369 * \\
{[0.208]}\end{array}$ & $\begin{array}{c}0.580 * * \\
{[0.229]}\end{array}$ & $\begin{array}{l}1.324 * \\
{[0.686]}\end{array}$ & $\begin{array}{l}1.245^{*} \\
{[0.664]}\end{array}$ & $\begin{array}{c}2.012 * * * \\
{[0.761]}\end{array}$ \\
\hline FORLIAB(-1) & $\begin{array}{c}0.008^{* * *} \\
{[0.002]}\end{array}$ & $\begin{array}{c}0.037^{* * *} \\
{[0.008]}\end{array}$ & $\begin{array}{c}0.008^{* * *} \\
{[0.002]}\end{array}$ & $\begin{array}{c}0.190 * * \\
{[0.076]}\end{array}$ & $\begin{array}{l}0.164 * * \\
{[0.078]}\end{array}$ & $\begin{array}{l}0.173 * \\
{[0.099]}\end{array}$ \\
\hline BUDGET_3y(-1) & $\begin{array}{c}0.038^{* * *} \\
{[0.007]}\end{array}$ & $\begin{array}{c}0.032^{* * *} \\
{[0.006]}\end{array}$ & $\begin{array}{c}0.015^{* *} \\
{[0.007]}\end{array}$ & $\begin{array}{c}3.876^{* *} \\
{[1.759]}\end{array}$ & $\begin{array}{c}0.807 \\
{[1.539]}\end{array}$ & $\begin{array}{c}1.116 \\
{[1.698]}\end{array}$ \\
\hline GAP_USA(-1) & $\begin{array}{c}0.001 \\
{[0.005]}\end{array}$ & $\begin{array}{c}-0.005 \\
{[0.004]}\end{array}$ & $\begin{array}{c}-0.004 \\
{[0.008]}\end{array}$ & $\begin{array}{c}0.001 \\
{[0.017]}\end{array}$ & $\begin{array}{c}-0.018 \\
{[0.014]}\end{array}$ & $\begin{array}{c}-0.013 \\
{[0.023]}\end{array}$ \\
\hline POPULATION & $\begin{array}{c}-0.091^{* * *} \\
{[0.025]}\end{array}$ & $\begin{array}{c}-0.070 * * * \\
{[0.023]}\end{array}$ & $\begin{array}{c}-0.034 \\
{[0.034]}\end{array}$ & $\begin{array}{c}-0.321 * * * \\
{[0.094]}\end{array}$ & $\begin{array}{c}-0.253 * * * \\
{[0.080]}\end{array}$ & $\begin{array}{c}-0.104 \\
{[0.109]}\end{array}$ \\
\hline KAOPEN(-1) & $\begin{array}{c}0.001 \\
{[0.023]}\end{array}$ & $\begin{array}{c}0.03 \\
{[0.021]}\end{array}$ & $\begin{array}{c}0.079 * * * \\
{[0.028]}\end{array}$ & $\begin{array}{c}0.002 \\
{[0.076]}\end{array}$ & $\begin{array}{l}0.106 * \\
{[0.065]}\end{array}$ & $\begin{array}{c}0.241 * * * \\
{[0.089]}\end{array}$ \\
\hline LANDLOCK & $\begin{array}{l}0.119 * \\
{[0.068]}\end{array}$ & $\begin{array}{c}0.091 \\
{[0.064]}\end{array}$ & $\begin{array}{c}0.073 \\
{[0.105]}\end{array}$ & $\begin{array}{c}0.415 \\
{[0.257]}\end{array}$ & $\begin{array}{c}0.301 \\
{[0.248]}\end{array}$ & $\begin{array}{c}0.262 \\
{[0.346]}\end{array}$ \\
\hline REPRESS & $\begin{array}{c}0.002 \\
{[0.020]}\end{array}$ & $\begin{array}{c}0.007 \\
{[0.020]}\end{array}$ & $\begin{array}{c}0.025 \\
{[0.024]}\end{array}$ & $\begin{array}{c}0.029 \\
{[0.063]}\end{array}$ & $\begin{array}{c}0.046 \\
{[0.066]}\end{array}$ & $\begin{array}{c}0.092 \\
{[0.081]}\end{array}$ \\
\hline BRITISH & $\begin{array}{c}-0.273 \\
{[0.205]}\end{array}$ & $\begin{array}{c}-0.358 \\
{[0.272]}\end{array}$ & $\begin{array}{c}-0.465^{* *} \\
{[0.233]}\end{array}$ & $\begin{array}{c}-1.016 \\
{[0.780]}\end{array}$ & $\begin{array}{l}-1.273 \\
{[0.959]}\end{array}$ & $\begin{array}{l}-1.604 * \\
{[0.900]}\end{array}$ \\
\hline FRENCH & $\begin{array}{c}-0.106 \\
{[0.200]}\end{array}$ & $\begin{array}{l}-0.232 \\
{[0.263]}\end{array}$ & $\begin{array}{l}-0.121 \\
{[0.208]}\end{array}$ & $\begin{array}{c}-0.47 \\
{[0.782]}\end{array}$ & $\begin{array}{l}-0.813 \\
{[0.947]}\end{array}$ & $\begin{array}{c}-0.605 \\
{[0.851]}\end{array}$ \\
\hline FUELS & $\begin{array}{c}0.117 \\
{[0.100]}\end{array}$ & $\begin{array}{c}0.205^{* *} \\
{[0.097]}\end{array}$ & $\begin{array}{c}-0.113 \\
{[0.114]}\end{array}$ & $\begin{array}{c}0.482 \\
{[0.377]}\end{array}$ & $\begin{array}{c}0.717^{* *} \\
{[0.331]}\end{array}$ & $\begin{array}{c}-0.469 \\
{[0.466]}\end{array}$ \\
\hline PRIMARY_MAT & $\begin{array}{c}-0.008 \\
{[0.064]}\end{array}$ & $\begin{array}{c}0.01 \\
{[0.066]}\end{array}$ & $\begin{array}{c}-0.211^{* *} \\
{[0.094]}\end{array}$ & $\begin{array}{c}0.034 \\
{[0.248]}\end{array}$ & $\begin{array}{c}0.02 \\
{[0.227]}\end{array}$ & $\begin{array}{c}-0.675^{* *} \\
{[0.338]}\end{array}$ \\
\hline E. Asia /Pacific & $\begin{array}{c}-0.217 \\
{[0.181]}\end{array}$ & $\begin{array}{c}-0.207 \\
{[0.137]}\end{array}$ & $\begin{array}{c}-0.033 \\
{[0.214]}\end{array}$ & $\begin{array}{c}-0.87 \\
{[0.650]}\end{array}$ & $\begin{array}{c}-0.561 \\
{[0.427]}\end{array}$ & $\begin{array}{c}-0.194 \\
{[0.717]}\end{array}$ \\
\hline Europe/C. Asia & $\begin{array}{c}-0.462 * * \\
{[0.189]}\end{array}$ & $\begin{array}{c}-0.537^{* *} \\
{[0.214]}\end{array}$ & $\begin{array}{l}-0.247 \\
{[0.209]}\end{array}$ & $\begin{array}{c}-1.689 * * \\
{[0.839]}\end{array}$ & $\begin{array}{c}-1.784^{* *} \\
{[0.894]}\end{array}$ & $\begin{array}{l}-1.206 \\
{[1.026]}\end{array}$ \\
\hline South Asia & $\begin{array}{c}0.141 \\
{[0.236]}\end{array}$ & $\begin{array}{c}-0.263^{*} \\
{[0.152]}\end{array}$ & $\begin{array}{c}0.314 \\
{[0.194]}\end{array}$ & $\begin{array}{c}0.48 \\
{[0.762]}\end{array}$ & $\begin{array}{c}-0.79 \\
{[0.517]}\end{array}$ & $\begin{array}{c}0.915 \\
{[0.631]}\end{array}$ \\
\hline Subsah. Africa & $\begin{array}{c}-0.012 \\
{[0.113]}\end{array}$ & $\begin{array}{c}0.039 \\
{[0.124]}\end{array}$ & $\begin{array}{c}0.451^{* * *} \\
{[0.157]}\end{array}$ & $\begin{array}{c}-0.102 \\
{[0.414]}\end{array}$ & $\begin{array}{c}0.175 \\
{[0.401]}\end{array}$ & $\begin{array}{c}1.340 * * \\
{[0.536]}\end{array}$ \\
\hline Latin America & $\begin{array}{c}-0.403^{* * *} \\
{[0.100]}\end{array}$ & $\begin{array}{c}-0.305^{* * *} \\
{[0.113]}\end{array}$ & $\begin{array}{c}0.003 \\
{[0.135]}\end{array}$ & $\begin{array}{c}-1.520^{* * *} \\
{[0.401]}\end{array}$ & $\begin{array}{c}-0.887^{* *} \\
{[0.371]}\end{array}$ & $\begin{array}{c}-0.08 \\
{[0.489]}\end{array}$ \\
\hline Constant & $\begin{array}{c}1.780 * * * \\
{[0.370]}\end{array}$ & $\begin{array}{c}1.795^{* * *} \\
{[0.346]}\end{array}$ & $\begin{array}{c}0.701 \\
{[0.437]}\end{array}$ & $\begin{array}{c}4.759 * * * \\
{[1.434]}\end{array}$ & $\begin{array}{c}4.546^{* * *} \\
{[1.338]}\end{array}$ & $\begin{array}{c}1.226 \\
{[1.577]}\end{array}$ \\
\hline Marginal effect & & & & $0.515^{*}$ & $0.484^{*}$ & $0.745^{* * *}$ \\
\hline Adj. Rsquared & 0.36 & 0.3 & 0.31 & 0.33 & 0.26 & 0.27 \\
\hline Obs. & 1831 & 1591 & 1590 & 1831 & 1591 & 1590 \\
\hline
\end{tabular}


Notes on Table 1: Standard errors in parentheses are based on a robust covariance matrix that accounts for heteroskedasticity and serial correlation within clusters. $* * *, * *, *$ denote significance levels of 1,5 , and 10 percent. All regressions include time dummies whose coefficients are not displayed, but are available upon request. The $\mathrm{R}^{2}$ in columns (4) - (6) is McFadden's pseudo $\mathrm{R}^{2}$.

Table 2: IV regressions - GMM-LPM and Probit

\begin{tabular}{|c|c|c|c|c|c|c|}
\hline & (1) & (2) & (3) & (4) & (5) & (6) \\
\hline & Peg (De-jure) & Peg (LYS) & Peg (RR) & Peg (De-jure) & Peg (LYS) & Peg (RR) \\
\hline & GMM-LPM & GMM-LPM & GMM-LPM & IV-Probit & IV-Probit & IV-Probit \\
\hline PRIVSHARE(-1) & $2.313^{* *}$ & $1.383^{*}$ & $1.882 * *$ & $5.746 * * *$ & 2.059 & $9.585^{* * *}$ \\
\hline & {$[0.985]$} & {$[0.802]$} & [0.954] & [1.782] & [1.681] & [2.289] \\
\hline FORLIAB(-1) & $0.010^{* * *}$ & $0.039 * * *$ & $0.011^{* * *}$ & $0.246^{* * *}$ & $0.199 * *$ & $0.376^{* * *}$ \\
\hline & [0.002] & [0.009] & [0.003] & {$[0.075]$} & {$[0.079]$} & {$[0.124]$} \\
\hline BUDGET_3y(-1) & $0.040 * * *$ & $0.029 * * *$ & $0.014^{* *}$ & $4.106^{* * *}$ & 1.476 & 1.140 \\
\hline & {$[0.006]$} & [0.006] & {$[0.007]$} & [1.127] & {$[1.065]$} & [1.095] \\
\hline GAP_USA(-1) & $-0.016^{*}$ & $-0.017 * *$ & -0.016 & $-0.034 * * *$ & $-0.032 * * *$ & $-0.081 * * *$ \\
\hline & {$[0.008]$} & {$[0.007]$} & {$[0.010]$} & {$[0.012]$} & {$[0.012]$} & {$[0.017]$} \\
\hline POPULATION & $-0.173 * * *$ & $-0.112^{* * *}$ & $-0.093 * *$ & $-0.536 * * *$ & $-0.335^{* * *}$ & $-0.418 * * *$ \\
\hline & [0.037] & [0.027] & {$[0.046]$} & [0.052] & [0.051] & {$[0.070]$} \\
\hline KAOPEN(-1) & 0.022 & $0.047^{*}$ & $0.077^{* * *}$ & 0.037 & $0.112^{* * *}$ & $0.274^{* * *}$ \\
\hline & {$[0.029]$} & {$[0.025]$} & [0.028] & {$[0.041]$} & [0.039] & [0.048] \\
\hline LANDLOCK & $0.186^{* *}$ & 0.076 & -0.039 & $0.526^{* * *}$ & 0.218 & -0.027 \\
\hline & {$[0.092]$} & [0.091] & [0.097] & {$[0.150]$} & {$[0.140]$} & {$[0.163]$} \\
\hline REPRESS & 0.015 & 0.006 & $0.046^{*}$ & $0.094^{* *}$ & 0.053 & $0.150 * * *$ \\
\hline & {$[0.025]$} & {$[0.026]$} & {$[0.025]$} & {$[0.037]$} & {$[0.036]$} & {$[0.042]$} \\
\hline BRITISH & $-0.552 * *$ & -0.502 & $-0.734 * *$ & $-2.760 * * *$ & $-2.433 * * *$ & $-7.594 * * *$ \\
\hline & [0.267] & {$[0.316]$} & [0.322] & {$[0.605]$} & [0.545] & [0.648] \\
\hline FRENCH & -0.331 & -0.354 & -0.325 & $-2.108^{* * *}$ & $-1.941 * * *$ & $-6.348 * * *$ \\
\hline & [0.259] & [0.305] & [0.313] & {$[0.601]$} & [0.538] & {$[0.625]$} \\
\hline FUELS & 0.216 & $0.313^{* * *}$ & 0.056 & $0.800 * * *$ & $0.920^{* * *}$ & 0.365 \\
\hline & [0.132] & [0.114] & [0.142] & [0.188] & {$[0.176]$} & {$[0.260]$} \\
\hline PRIMARY_MAT & -0.189 & -0.065 & -0.157 & $-0.298^{* *}$ & 0.052 & $-0.606 * * *$ \\
\hline & [0.118] & [0.098] & [0.132] & [0.144] & [0.134] & {$[0.162]$} \\
\hline Constant & $2.515^{* * *}$ & $1.956 * * *$ & $1.321^{* *}$ & $9.365^{* * *}$ & $6.019 * * *$ & $10.292^{* * *}$ \\
\hline & {$[0.443]$} & {$[0.378]$} & {$[0.548]$} & [0.967] & [0.801] & [0.738] \\
\hline Adj. Rsquared & 0.19 & 0.24 & 0.26 & & & \\
\hline Exogeneity of excl. instruments ( $p$-value) & 0.41 & 0.35 & 0.63 & 0.37 & 0.48 & 0.22 \\
\hline Exogeneity of PRIVSHARE(-1) (p-value) & 0.031 & 0.110 & 0.064 & 0.008 & 0.468 & 0.000 \\
\hline Underidentification ( $p$-value) & 0.005 & 0.002 & 0.015 & & & \\
\hline Obs. & 1477 & 1308 & 1314 & 1478 & 1309 & 1315 \\
\hline
\end{tabular}

Notes on Table 2: Standard errors in parentheses are based on a robust covariance matrix that accounts for heteroskedasticity and serial correlation within clusters. ***,**,* denote significance levels of 1,5 , and 10 percent. All regressions include regional and time dummies whose coefficients are not displayed, but are available upon request. Columns (1) - (3) are based on the GMM estimation of a linear probability model while columns (4) - (6) are based on Newey's (1987) two-step estimator as described in Wooldridge (2002:472 ff.). The instruments used in the regressions underlying columns (1) - (3) and (6) are CREDREG_3Y(-1), 
INFLA_3Y(-1) as well as GROWTH_3Y(-1). For columns (4) and (5) only CREDREG_3Y(-1) and GROWTH_3Y(-1) were used as instruments. To test for the exogeneity of the excluded instruments, columns (1) - (3) refer to the p-value associated with Hansen's (1982) J-statistic while columns (4) - (6) refer to the Amemiya-Lee-Newey minimum $\chi^{2}$-statistic. The exogeneity of PRIVSHARE(-1) is tested using a C-(differencein-Sargan) test in columns (1) - (3) while columns (4) - (6) refer to the exogeneity test as described in Wooldridge (2002:473 ff.). The test for underidentification reported in columns (1) - (3) is based on the Kleibergen-Paap rk-statistic.

Table 3: Sample Variation - Only years after 1985

\begin{tabular}{|c|c|c|c|c|c|c|}
\hline & (1) & $(2)$ & (3) & (4) & (5) & (6) \\
\hline & Peg (De-jure) & Peg (LYS) & Peg (RR) & Peg (De-jure) & Peg (LYS) & Peg (RR) \\
\hline & OLS & OLS & OLS & GMM-LPM & GMM-LPM & GMM-LPM \\
\hline \multirow[t]{2}{*}{ PRIVSHARE(-1) } & $0.421^{*}$ & $0.386^{*}$ & $0.470^{*}$ & $2.291 * *$ & $1.444^{* *}$ & 1.106 \\
\hline & {$[0.230]$} & {$[0.216]$} & {$[0.259]$} & {$[1.000]$} & {$[0.734]$} & {$[0.816]$} \\
\hline \multirow[t]{2}{*}{ FORLIAB(-1) } & $0.018 * * *$ & $0.043 * * *$ & $0.020 * * *$ & $0.019 * * *$ & $0.042 * * *$ & $0.022 * * *$ \\
\hline & {$[0.003]$} & {$[0.008]$} & {$[0.004]$} & {$[0.004]$} & {$[0.008]$} & {$[0.004]$} \\
\hline \multirow[t]{2}{*}{ BUDGET_3y(-1) } & $0.038 * * *$ & $0.030 * * *$ & $0.016 * *$ & $0.038 * * *$ & $0.025^{* * *}$ & $0.014 *$ \\
\hline & {$[0.009]$} & {$[0.007]$} & {$[0.007]$} & {$[0.008]$} & {$[0.006]$} & {$[0.007]$} \\
\hline \multirow[t]{2}{*}{ GAP_USA(-1) } & 0 & -0.006 & -0.003 & $-0.019 *$ & $-0.019 * * *$ & -0.01 \\
\hline & {$[0.006]$} & [0.005] & [0.009] & {$[0.010]$} & {$[0.007]$} & {$[0.011]$} \\
\hline \multirow[t]{2}{*}{ POPULATION } & $-0.078 * * *$ & $-0.052^{*}$ & -0.03 & $-0.157^{* * *}$ & $-0.089 * * *$ & -0.071 \\
\hline & {$[0.027]$} & {$[0.026]$} & {$[0.037]$} & {$[0.039]$} & {$[0.028]$} & [0.047] \\
\hline \multirow[t]{2}{*}{ KAOPEN(-1) } & -0.001 & $0.041 *$ & 0.046 & 0.017 & $0.063^{* *}$ & 0.042 \\
\hline & {$[0.025]$} & {$[0.023]$} & {$[0.029]$} & {$[0.028]$} & {$[0.025]$} & {$[0.028]$} \\
\hline \multirow[t]{2}{*}{ LANDLOCK } & $0.150 *$ & 0.097 & 0.085 & $0.212^{* *}$ & 0.073 & -0.057 \\
\hline & {$[0.085]$} & {$[0.081]$} & {$[0.110]$} & {$[0.106]$} & {$[0.103]$} & {$[0.102]$} \\
\hline \multirow[t]{2}{*}{ REPRESS } & -0.011 & 0.009 & 0.014 & 0.008 & 0.008 & 0.04 \\
\hline & {$[0.023]$} & {$[0.023]$} & {$[0.028]$} & {$[0.027]$} & {$[0.027]$} & {$[0.030]$} \\
\hline \multirow[t]{2}{*}{ BRITISH } & -0.299 & -0.337 & $-0.427^{*}$ & $-0.659 * * *$ & $-0.509 *$ & $-0.836 * * *$ \\
\hline & {$[0.208]$} & {$[0.272]$} & {$[0.242]$} & {$[0.238]$} & {$[0.291]$} & {$[0.232]$} \\
\hline \multirow[t]{2}{*}{ FRENCH } & -0.066 & -0.237 & -0.063 & $-0.379 *$ & -0.389 & $-0.397^{*}$ \\
\hline & {$[0.198]$} & {$[0.260]$} & {$[0.213]$} & {$[0.224]$} & {$[0.275]$} & {$[0.217]$} \\
\hline \multirow[t]{2}{*}{ FUELS } & 0.151 & $0.241^{* *}$ & -0.132 & $0.237 * *$ & $0.349 * * *$ & 0 \\
\hline & {$[0.100]$} & {$[0.101]$} & {$[0.122]$} & {$[0.118]$} & [0.108] & [0.139] \\
\hline \multirow[t]{2}{*}{ PRIMARY_MAT } & -0.064 & -0.013 & $-0.195 *$ & $-0.240 *$ & -0.067 & -0.096 \\
\hline & {$[0.078]$} & {$[0.080]$} & {$[0.109]$} & {$[0.142]$} & {$[0.105]$} & {$[0.133]$} \\
\hline \multirow[t]{2}{*}{ Constant } & $1.323^{* * *}$ & $1.358 * * *$ & 0.59 & $2.458 * * *$ & $1.708^{* * *}$ & $1.195^{* *}$ \\
\hline & [0.419] & {$[0.381]$} & {$[0.452]$} & {$[0.521]$} & [0.405] & {$[0.550]$} \\
\hline Adj. Rsquared & 0.3 & 0.28 & 0.27 & 0.18 & 0.23 & 0.31 \\
\hline Exogeneity of excl. instruments ( $p$-value) & & & & 0.65 & 0.6 & 0.54 \\
\hline Exogeneity of PRIVSHARE(-1) (p-value) & & & & 0.039 & 0.096 & 0.278 \\
\hline Underidentification (p-value) & & & & 0.005 & 0.001 & 0.012 \\
\hline Obs. & 1342 & 1178 & 1164 & 1102 & 992 & 983 \\
\hline
\end{tabular}

Notes on Table 3: Standard errors in parentheses are based on a robust covariance matrix that accounts for heteroskedasticity and serial correlation within clusters. ${ }^{* *}, * *, *$ denote significance levels of 1,5 , and 10 
percent. All regressions include regional and time dummies whose coefficients are not displayed, but are available upon request. Columns (4) - (6) are based on the GMM/TSLS estimation of a linear probability model. The instruments used in the regressions underlying columns (1) - (3) and (6) are CREDREG_3Y(-1), INFLA $3 \mathrm{Y}(-1)$ as well as GROWTH $3 \mathrm{Y}(-1)$. To test for the exogeneity of the excluded instruments, columns (4) - (6) refer to the p-value associated with Hansen's (1982) J-statistic. The exogeneity of PRIVSHARE(-1) is tested using a C-(difference-in-Sargan) test in columns (4) - (6). The test for underidentification reported in columns (4) - (6) is based on the Kleibergen-Paap rk-statistic.

Table 4: Sample Variation - No "Freely-Falling" Episodes

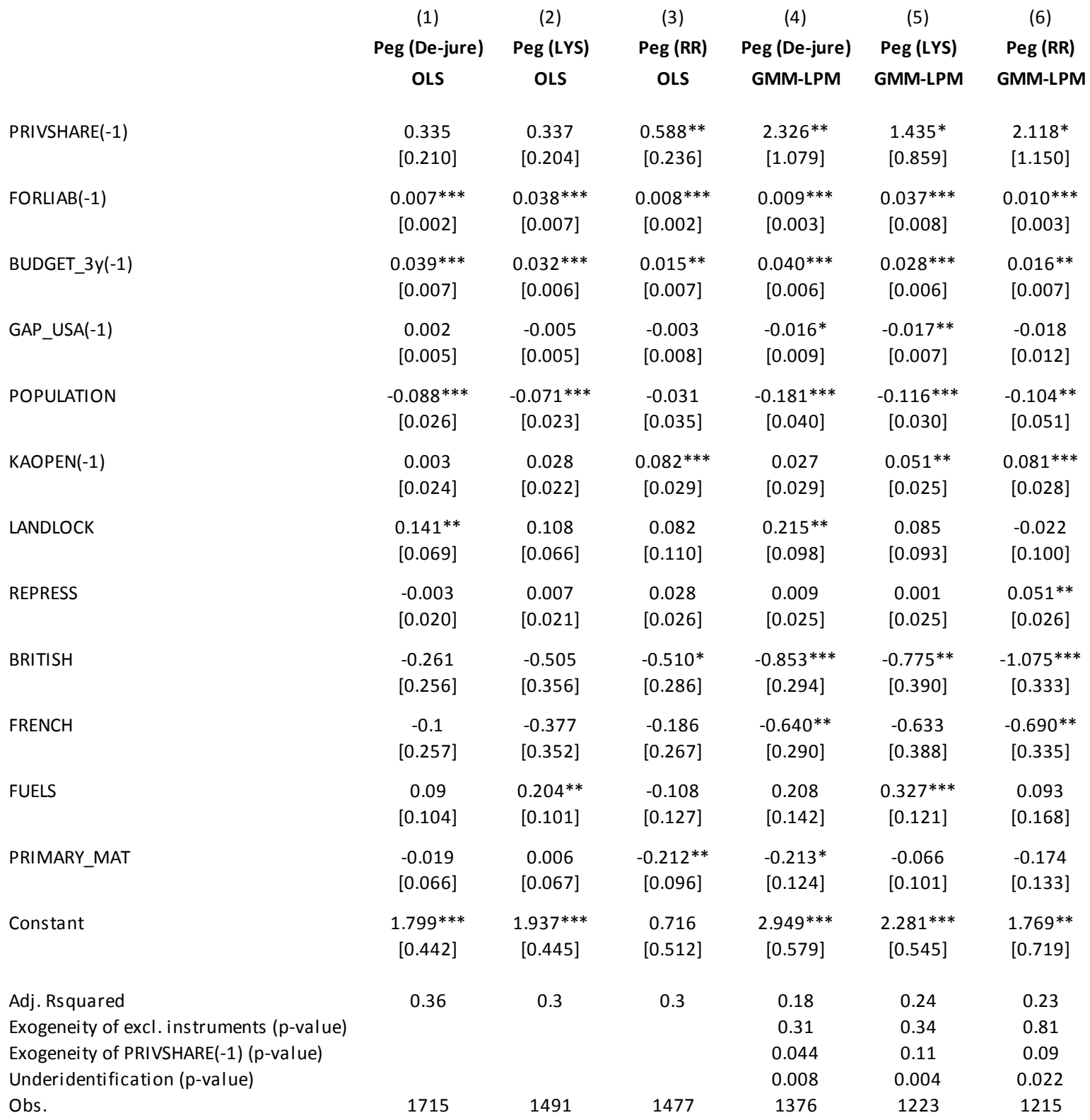

Notes on Table 4: Standard errors in parentheses are based on a robust covariance matrix that accounts for heteroskedasticity and serial correlation within clusters. $* * *, * * *$ denote significance levels of 1,5 , and 10 percent. All regressions include regional and time dummies whose coefficients are not displayed, but are available upon request. Columns (4) - (6) are based on the GMM/TSLS estimation of a linear probability model. The instruments used in the regressions underlying columns (1) - (3) and (6) are CREDREG_3Y(-1), INFLA $3 \mathrm{Y}(-1)$ as well as GROWTH $3 \mathrm{Y}(-1)$. To test for the exogeneity of the excluded instruments, columns $(4)-(\overline{6})$ refer to the p-value associated with Hansen's (1982) J-statistic. The exogeneity of PRIVSHARE(-1) is tested using a C-(difference-in-Sargan) test in columns (4) - (6). The test for underidentification reported in columns (4) - (6) is based on the Kleibergen-Paap rk-statistic. 


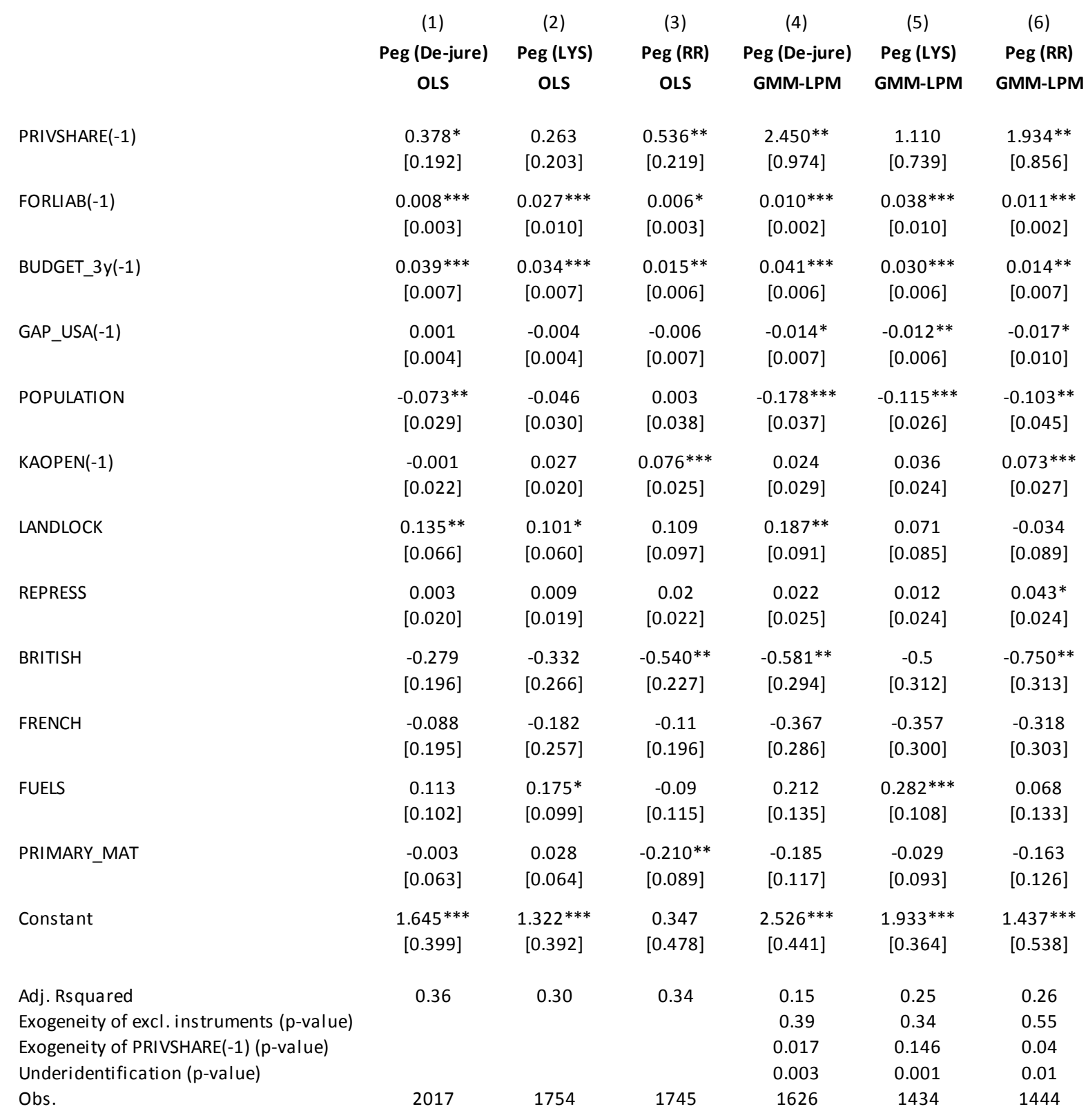

Notes on Table 5: Standard errors in parentheses are based on a robust covariance matrix that accounts for heteroskedasticity and serial correlation within clusters. ${ }^{* * *}, * *, *$ denote significance levels of 1,5 , and 10 percent. All regressions include regional and time dummies whose coefficients are not displayed, but are available upon request. Columns (4) - (6) are based on the GMM/TSLS estimation of a linear probability model. The instruments used in the regressions underlying columns (1) - (3) and (6) are CREDREG_3Y(-1), INFLA_3Y(-1) as well as GROWTH_3Y(-1). To test for the exogeneity of the excluded instruments, columns (4) - (6) refer to the p-value associated with Hansen's (1982) J-statistic. The exogeneity of PRIVSHARE(-1) is tested using a C-(difference-in-Sargan) test in columns (4) - (6). The test for underidentification reported in columns (4) - (6) is based on the Kleibergen-Paap rk-statistic. 